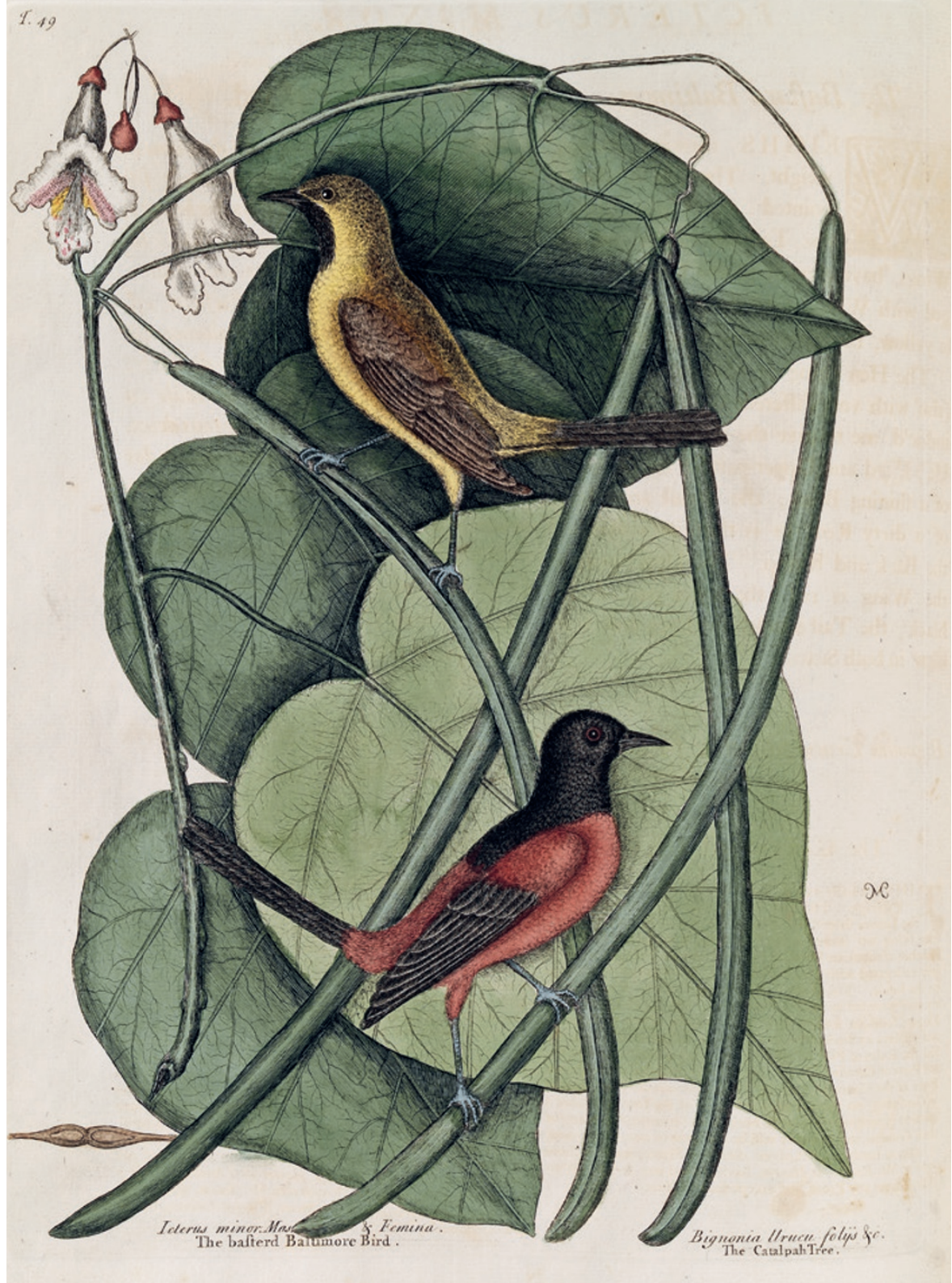

Mark Catesby's depiction of Catalpa bignonioides and the orchard oriole (Icterus spurius).

\title{
Revelations of a
}

wild continent

\section{Linda Lear praises a study of one of the first naturalists to document North America's flora and fauna.}

\section{$\mathrm{T}$} he mid-eighteenth century was the heyday of natural history. Scientists were redrawing the world map, discovering land bridges between continents and documenting new species of flora and fauna. Members of Britain's elite Royal Society, such as physician and collector Hans Sloane, were particularly interested in the classification of these species, as were many in the broader scientific community, including those at the Chelsea Physic Garden in London who were tasked with evaluating and classifying specimens. Documenting the natural world became a consuming passion.

In July 1747, Mark Catesby (1682/3-1749), a largely self-taught naturalist, presented the final sections of a massive study to the Royal Society. Two decades in the making, The Natural History of Carolina, Florida and the Bahama Islands was the first comprehensive

account of North American flora and fauna ever published. It comprised more than 200 handcoloured etchings based on hundreds of preparatory drawings and notes, with descriptions of each in English and French. Royal Society secretary Cromwell Mortimer hailed them as "the most magnificent work I know since the Art of printing has been discovered".

Now, the splendid

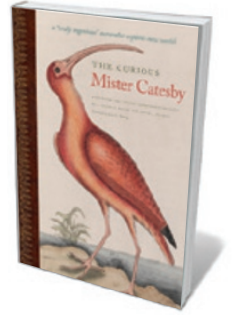

The Curious

Mister Catesby: A

"Truly Ingenious" Naturalist Explores New Worlds EDITED BY E. CHARLES NELSON AND DAVID J. ELLIOTT

Univ. Georgia Press: 2015.

anthology The Curious Mister Catesby shows that this praise was not exaggerated. Marking the tercentenary of Catesby's first visit to America in 1712-19, this comprehensive, lavishly illustrated work illuminates the many ways in which Catesby changed how the natural world was perceived and portrayed, suggesting for the first time a dynamic ecological relationship between flora and fauna. Edited by botanist Charles Nelson and David Elliott, executive director of the Catesby Commemorative Trust, it contains reproductions of paintings, engravings, photographs and maps, as well as essays by 25 scholars in fields from art history to the study of molluscs.

Although no likeness of Catesby exists and little is known about him, his evident dedication to documenting nature's marvels marks him as an ambitious and innovative plantsman, an inquisitive natural scientist and an artist of talent and energy. His friend Emanuel Mendez da Costa, an English botanist, drew him as "tall, meagre ... and of a silent disposition; but when he contracted a friendship was communicative, and affable". Catesby was elected to the Royal Society in 1734, and in 1747 he completed an appendix to his Natural History, which included 20 extra drawings of species hitherto unknown to Britain, such as the silky camellia, Stewartia malacodendron.

Catesby sailed to Williamsburg, Virginia, in 1712, to collect botanical specimens for an illustrated natural history. His explorations of the Tidewater region in eastern Virginia and the wilderness east of the Appalachian Mountains were partially supported by horticultural patrons in London, eager for a supply of hardy North American species, and by like-minded colonial botanists.

He returned to London in 1719 with a collection of seeds, including those of the passion flower Passiflora lutea. The specimens so interested naturalists such as William Sherard that Catesby was able to raise funds for a second trip, arriving in Charleston (then Charles Town), South Carolina, in 1722. He explored perhaps as far as northeastern Georgia (then 
part of Spanish Florida) more systematically than before, visiting each region in every season. Native American guides helped to carry his paints, mostly fast-drying watercolours and gouache, as well as boxes of specimens, drawings and field notes; they also saved him from venomous snakes and alligator-filled swamps, and shot game for food.

At the end of 1725, Catesby spent time in the Bahamas painting fishes, then returned to London. Unable to afford to hire a copperplate engraver, he mastered the technique himself, with the help of French artist Joseph Goupy. He planned 100 etchings, mainly of birds, for Volume I; another 100 would comprise a second volume, showing fishes, crustaceans, reptiles, amphibians, insects, a few mammals and a handful of plants.

Catesby found birds the most beautiful of fauna. He was among the first to show associations between plants and animals, for example in his painting of the Greater Antillean bullfinch (Loxigilla violacea) with the poisonwood tree Metopium toxiferum. He contributed significantly to the understanding of avian migration, a topic of heated debate at a time when many believed that birds vanished in winter to hibernate in some form of suspended animation. Catesby argued in his paper 'Of Birds of Passage' (M. Catesby Phil. Trans. 44, 435-444; 1746) that birds fly to

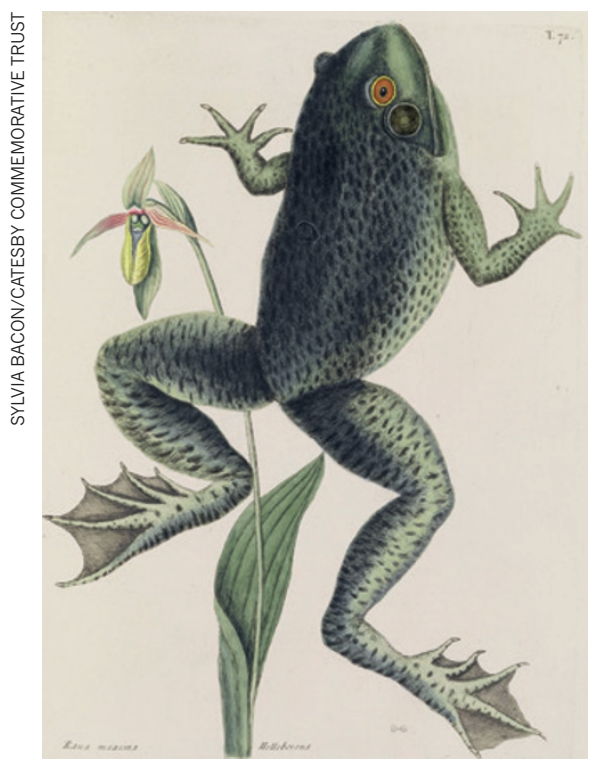

'The Bull Frog' - Lithobates catesbeianus.

warmer climates in winter, spurred by seasonal changes and availability of food.

An estimated 200 copies of Catesby's two volumes were printed, with hand-coloured engraved plates. These and two later editions were avidly sought by natural scientists and plant collectors. In 1768, King George III bought Catesby's original 263 watercolour field studies; they are now part of the British Royal Collection. Sadly, Catesby's achievements were diminished by the souring of $>$

\section{Books in brief}

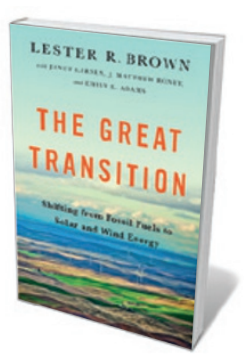

The Great Transition: Shifting from Fossil Fuels to Solar and Wind Energy

Lester R. Brown with Janet Larsen, J. Matthew Roney and Emily E. Adams W. W. NORTON (2015)

This lucid overview of world energy is surprisingly devoid of gloom. With colleagues at the Earth Policy Institute in Washington DC, environmental analyst Lester Brown suggests that the hold of fossil fuels is finally weakening. Wind and solar power are poised to fill the gap, driven by falling prices and increased environmental awareness. This treatise depicts future energy supply and generation systems that are radically different from today's, and far superior.

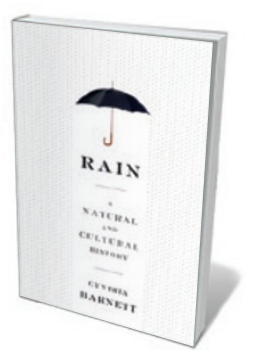

Rain: A Natural and Cultural History

Cynthia Barnett CROWN (2015)

In this romp through rain from pre-history to now, journalist Cynthia Barnett shows how entwined all Earth (and most human) systems are with this life-giving and life-taking precipitation. From droughts that devastated ancient civilizations and floods that drown settlements today, to the rain that inspired cultural offerings such as music from Bo Diddley and Frédéric Chopin, Barnett shows that rain is to be respected and celebrated. She looks at the science of deluge, both whimsical — a rain of frogs in Britain in 1954 — and disastrous, including acid rain and catastrophic flooding.

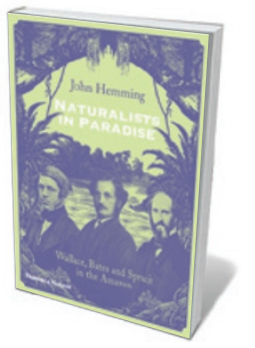

Naturalists in Paradise: Wallace, Bates and Spruce in the Amazon John Hemming THAMES AND HUDSON (2015)

Nineteenth-century biology often seems to have involved as much adventuring as academia. Geographer John Hemming finds a wonderful tale in the Amazonian sojourn of co-discoverer of evolution Alfred Russel Wallace and his fellow nature-watchers, entomologist Henry Walter Bates and botanist Richard Spruce. Hemming shows how the challenges and triumphs of their time in this haven of biodiversity shaped these naturalists, and how they in turn shaped science through specimen collection and papers. An excellent addition to the slew of biographies of eminent Victorians.

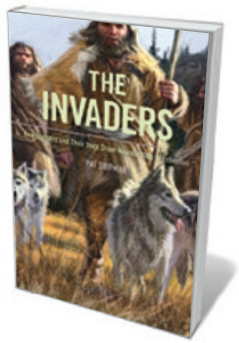

The Invaders: How Humans and Their Dogs Drove Neanderthals to Extinction

Pat Shipman BeLKNAP PRESS (2015)

Are humans the ultimate invasive species? So contends anthropologist Pat Shipman — and Neanderthals, she opines, were among our first victims. The relationship between Homo sapiens and Homo neanderthalensis is laid out cleanly, along with genetic and other evidence. Shipman posits provocatively that the deciding factor in the triumph of our ancestors was the domestication of wolves. Perhaps more troubling is the concept of early humans as invaders, rather than just another species finding its way.

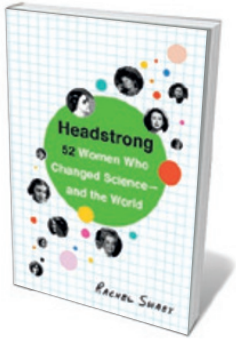

Headstrong: $\mathbf{5 2}$ Women Who Changed Science - and the World Rachel Swaby BROADWAY (2015)

A cursory glance at gender balance across science will show that women have still not gained equality. Journalist Rachel Swaby aims to present a comprehensive set of role models for the next generation, who should claim this parity. She ranges from seventeenth-century naturalist Maria Sibylla Merian to astronaut Sally Ride. But cramming 52 awe-inspiring researchers into just over 200 pages reduces them to career bullet points, shorn of context. These women, and those who will follow them, deserve more. Daniel Cressey 


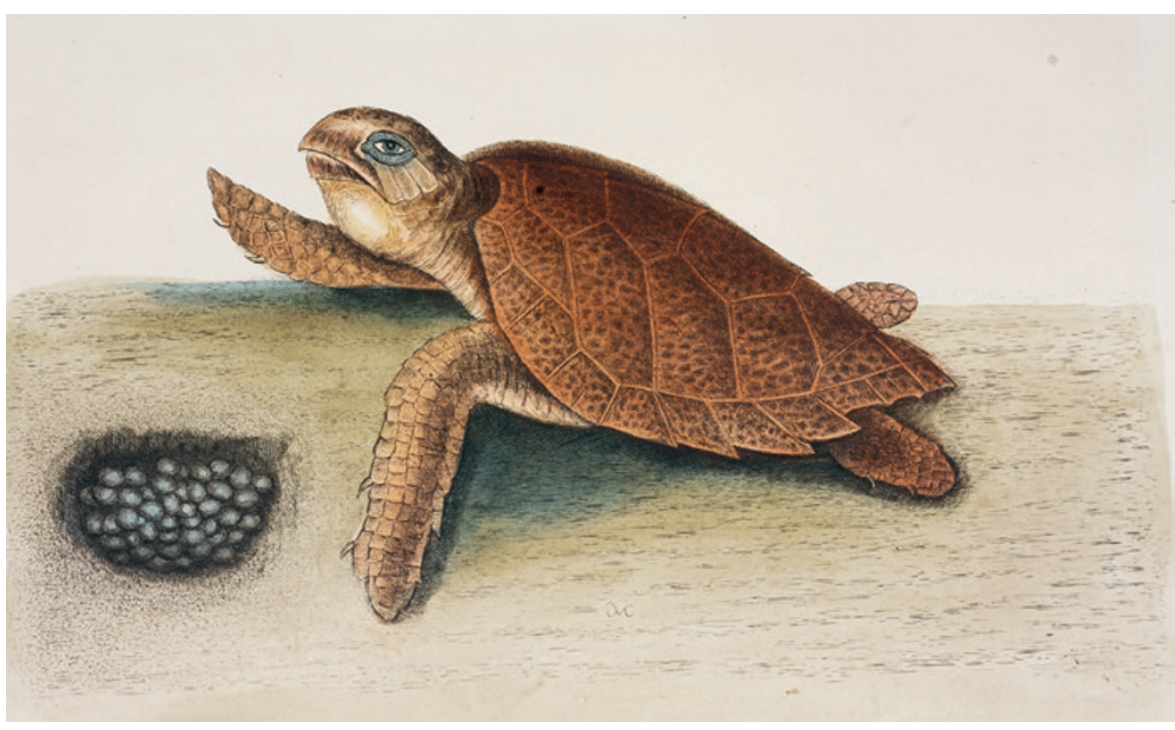

Catesby's rendition of Eretmochelys imbricata, the hawksbill sea turtle. relations between the United States and Britain after the American War of Independence (1775-83). As US artists and naturalists such as Alexander Wilson, William Bartram and John James Audubon became popular, the British pioneer - whose pre-Linnean classifications were by then outmoded - was largely forgotten. There were so few copies of Catesby's volumes in existence by the midnineteenth century that his work was rarely seen, further contributing to his obscurity.

The Curious Mister Catesby will stand for many years as the best critical analysis of his work, and of the groundbreaking natural science that his curiosity inspired.

Linda Lear is a historian of the American environment, an authority on Rachel Carson and author of Beatrix Potter: The Extraordinary Life of a Victorian Genius. e-mail: linda@lindalear.com

\section{Total recall, welcome oblivion}

\section{Alison Abbott enjoys a collection of essays on memory and forgetting.}

$\mathrm{H}$ istorian of psychology Douwe Draaisma knows well how to weave science, history and literature into irresistible tales. Forgetting, his latest collection of essays around the theme of memory, is - like his successful Nostalgia Factory (Yale University Press, 2013) - hard to put down.

His vivid tour through the history of memory-repression theories brings home how dangerous and wrong, yet persistent, were the ideas of Sigmund Freud and his intellectual heirs. Freud thought that traumatic memories and shameful thoughts could be driven from the consciousness, but not forgotten. They would simmer in the unconscious, influencing behaviour. He maintained that forcing them out with psychoanalysis, and confronting patients with them, would be curative.

Draaisma relates the case of an 18-year-old whom Freud dubbed Dora, diagnosed in 1900 with 'hysteria'. Dora's family refused to believe that the husband of her father's mistress had made sexual advances to her. Among other absurdities, Freud told Dora that her nervous cough reflected her repressed desire to fellate the man. Dora broke off the therapy, which Freud saw as proof of his theory. He thought that patients will naturally resist reawakening painful thoughts.

What Dora did not buy, plenty of others did. Psychoanalysis boomed, becoming lucrative. Its principles

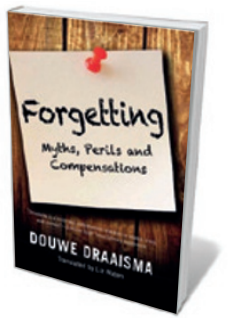

Forgetting: Myths, Perils and Compensations DOUWE DRAAISMA, TRANSLATED BY LIZ WATERS

Yale Univ. Press: 2015 now know from studies of post-traumatic stress disorder that traumatic memories are impossible to repress. They flood into the conscious mind in horrifying flashbacks.

Still, as Draaisma shows, theories of memory repression remain stubbornly attractive. We learn that revered Canadian neurosurgeon Wilder Penfield contributed to their longevity. During surgery for epilepsy, he electrically stimulated points on the surface of conscious patients' brains, and asked the patients what they felt. He was one of the first to map the functions of the sensory and motor cortices. His cartoon of a homunculus with body parts in proportion to the brain space dedicated to them - big lips, for example, and huge hands on spindly arms - is a neuroscience icon.

More controversial was his reading of another experiment. When Penfield stimulated the temporal lobe, his patients reported flashes of dream-like sensations such as the sound of a carnival; he interpreted these as memory traces. He thought that nothing was truly forgotten, and that buried memories could be reactivated. This concept of total recall resonated for a long time in the public imagination. Recent interpretations of his work, however, debunk the idea that he had picked up true memory traces. Fewer than $10 \%$ of people experienced any sensation during temporal-lobe stimulation, and of those that did, the actual words recorded in their notes rarely corresponded to things that could be real memories. As Draaisma drolly notes, Penfield's patients reported nothing worthy of repression anyway. Only "snippets of respectable but humdrum lives ... no incestuous desires, no masturbation fantasies".

In another essay, the patient H. M. (Henry Molaison), who was unable to lay down fresh memories after experimental epilepsy surgery, gets a new biography revealing the misdemeanours of his surgeon. Elsewhere, Draaisma muses on aides-memoires such as photographs, and techniques for forgetting. However, one or two essays show the strains of stretching the formula of memory-related essays to the margin of the theme, where the impact is less important or interesting.

Alison Abbott is Nature's senior European correspondent. 